\title{
Methylothermus subterraneus sp. nov., a moderately thermophilic methanotroph isolated from a terrestrial subsurface hot aquifer
}

Correspondence
Hisako Hirayama
hirayamah@jamstec.go.jp

\author{
Hisako Hirayama, ${ }^{1}$ Yohey Suzuki, ${ }^{2}$ Mariko Abe, ${ }^{1}$ Masayuki Miyazaki, ${ }^{1}$ \\ Hiroko Makita, ${ }^{1}$ Fumio Inagaki, ${ }^{3}$ Katsuyuki Uematsu ${ }^{4}$ and Ken Takai ${ }^{1}$ \\ ${ }^{1}$ Institute of Biogeosciences, Japan Agency for Marine-Earth Science \& Technology (JAMSTEC), \\ 2-15 Natsushima-cho, Yokosuka, 237-0061, Japan \\ ${ }^{2}$ Institute for Geo-Resources \& Environment, National Institute of Advanced Industrial Science and \\ Technology (AIST), 1-1-1 Higashi, Tsukuba, 305-8567, Japan \\ ${ }^{3}$ Geomicrobiology Group, Kochi Institute for Core Sample Research, Japan Agency for Marine-Earth \\ Science \& Technology (JAMSTEC), Monobe B200, Nankoku, Kochi, 783-8502, Japan \\ ${ }^{4}$ Department of Technical Services, Marine Works Japan Ltd, 2-16-32 Kamariyahigashi, \\ Kanazawa-ku, Yokohama, 236-0042, Japan
}

\begin{abstract}
A novel methane-oxidizing bacterium, strain $\mathrm{HTM}^{\top} 5^{\top}$, was isolated from subsurface hot aquifer water from a Japanese gold mine. Strain $\mathrm{HTM}^{\mathrm{T}} 5^{\top}$ was a Gram-negative, aerobic, motile, coccoid bacterium with a single polar flagellum and the distinctive intracytoplasmic membrane arrangement of a type I methanotroph. Strain $\mathrm{HTM}^{\mathrm{T}} 5^{\top}$ was a moderately thermophilic, obligate methanotroph that grew on methane and methanol at $37-65^{\circ} \mathrm{C}$ (optimum $55-60{ }^{\circ} \mathrm{C}$ ). The isolate grew at $\mathrm{pH} 5.2-7.5$ (optimum 5.8-6.3) and with $0-1 \% \mathrm{NaCl}$ (optimum $0-0.3 \%$ ). The ribulose monophosphate pathway was operative for carbon assimilation. The DNA G+C content was $54.4 \mathrm{~mol} \%$ and the major fatty acids were $\mathrm{C}_{16: 0}(52.0 \%)$ and $\mathrm{C}_{18: 1} \omega 7 \mathrm{c}(34.8 \%)$.

Phylogenetic analysis of the $16 \mathrm{~S}$ rRNA gene sequence indicated that strain $\mathrm{HTM}^{\top} 5^{\top}$ was closely related to Methylothermus thermalis $\mathrm{MYHT}^{\top}$ (99.2\% 16S rRNA gene sequence similarity), which is within the class Gammaproteobacteria. However, DNA-DNA relatedness between strain $\mathrm{HTM}^{\top} 5^{\top}$ and Methylothermus thermalis $\mathrm{MYHT}^{\top}$ was $\leqslant 39 \%$. On the basis of distinct phylogenetic, chemotaxonomic and physiological characteristics, strain $\mathrm{HTM}^{\top} 5^{\top}$ represents a novel species of the genus Methylothermus, for which the name Methylothermus subterraneus sp. nov. is proposed. The type strain is $\mathrm{HTM}^{\top} 5^{\top}\left(=\mathrm{JCM} 13664^{\top}=\mathrm{DSM} 19750^{\top}\right)$.
\end{abstract}

The existence of aerobic methanotrophs inhabiting extreme environments has been verified so far by cultivation experiments and direct detection of the methane monooxygenase genes specific to aerobic methanotrophs. Thermophilic methanotrophs have been isolated from such extreme environments and consist of the gammaproteobacterial (type I) genera Methylothermus, Methylocaldum and Methylococcus and the verrucomicrobial genus Methylacidiphilum (Bodrossy et al., 1997; Bowman et al., 1993; Eshinimaev et al.,

Abbreviations: pMMO, particulate methane monooxygenase; RuMP, ribulose monophosphate; sMMO, soluble methane monooxygenase.

The GenBank/EMBL/DDBJ accession numbers for the $16 \mathrm{~S}$ rRNA, particulate methane monooxygenase and 3-hexulose-6-phosphate synthase and 6-phospho-3-hexuloisomerase gene sequences of strain $\mathrm{HTM}_{5}{ }^{\mathrm{T}}$ are AB536747, AB536748 and AB591834, respectively.

A supplementary figure and two supplementary tables are available with the online version of this paper.
2004; Op den Camp et al., 2009; Tsubota et al., 2005). The genus Methylothermus represents the most thermophilic methanotrophs isolated so far. It was reported that Methylothermus sp. strain HB, isolated from Hungarian hot springs, grew at temperatures up to $72{ }^{\circ} \mathrm{C}$ (Bodrossy et al., 1999). Unfortunately, strain HB was lost before it received a validly published name within the genus Methylothermus. The genus name Methylothermus was validly published by Tsubota et al. (2005), with strain $\mathrm{MYHT}^{\mathrm{T}}$ as the type strain of the type species Methylothermus thermalis gen. nov., sp. nov. Although strains $\mathrm{HB}$ and $\mathrm{MYHT}^{\mathrm{T}}$ seemed to belong to different species within the genus Methylothermus, on the basis of their low 16S rRNA gene sequence similarity (92.6\%), Methylothermus thermalis is currently the only species and strain $\mathrm{MYHT}^{\mathrm{T}}$ is the only currently extant strain of the genus Methylothermus.

In a previous study by our laboratory, a $16 \mathrm{~S}$ rRNA gene sequence that was closely related to the genus Methylothermus 
was identified in subsurface geothermal aquifer water $\left(71.5^{\circ} \mathrm{C}\right.$ ) in the Hishikari gold mine, Japan (Inagaki et al., 2003). Further culture-independent analyses of microbial mats found on the tunnel floor in the gold mine, where the geothermal water $\left(69^{\circ} \mathrm{C}\right)$ was naturally discharging through the cracks of the basement rocks, demonstrated the predominance of methanotrophs of the genus Methylothermus in the mat community (Hirayama et al., 2005b). On the basis of these results, cultivation experiments were attempted by targeting a variety of metabolic pathways and several novel thermophilic chemolithoautotrophs have been isolated and characterized (Hirayama et al., 2005a; Takai et al., 2002, 2003). In this report, we describe a novel thermophilic methanotroph, strain $\mathrm{HTM}_{5} 5^{\mathrm{T}}$, from the gold mine microbial communities. Based on the taxonomic characterization, this report proposes that strain $\mathrm{HTM} 55^{\mathrm{T}}$ represents a novel species of the genus Methylothermus.

Sample mixtures of hot water and microbial mats were taken from the discharge point $\left(69^{\circ} \mathrm{C}\right)$ of the subsurface aquifer water in the Hishikari gold mine, Kagoshima, Japan. The site description has previously been reported in detail (Hirayama et al., 2005b). For cultivation, Mmj medium was prepared by adding $15 \mu \mathrm{M} \mathrm{CuSO}_{4}$ to mj medium [containing $\mathrm{l}^{-1}: 0.5 \mathrm{~g} \mathrm{NaHCO}_{3}, 0.25 \mathrm{~g} \mathrm{NH}_{4} \mathrm{Cl}$, $0.25 \mathrm{~g} \mathrm{NaNO}_{3}, 3.0 \mathrm{~g} \mathrm{NaCl}, 14 \mathrm{mg} \mathrm{K} \mathrm{HPO}_{4}, 80 \mathrm{mg} \mathrm{CaCl}$, $0.34 \mathrm{~g} \mathrm{MgSO}_{4} .7 \mathrm{H}_{2} \mathrm{O}, 0.42 \mathrm{~g} \mathrm{MgCl}_{2} \cdot 6 \mathrm{H}_{2} \mathrm{O}, 33 \mathrm{mg} \mathrm{KCl}$, $0.05 \mathrm{mg} \mathrm{NiCl}{ }_{2} .6 \mathrm{H}_{2} \mathrm{O}, 0.05 \mathrm{mg} \mathrm{Na} \mathrm{SeO}_{3} .5 \mathrm{H}_{2} \mathrm{O}, 0.01 \mathrm{mg}$ $\mathrm{Na}_{2} \mathrm{WO}_{4}, 2 \mathrm{mg} \mathrm{Fe}\left(\mathrm{NH}_{4}\right)_{2}\left(\mathrm{SO}_{4}\right)_{2} \cdot 6 \mathrm{H}_{2} \mathrm{O}, 1 \mathrm{ml}$ trace mineral solution (Balch et al., 1979) and $1 \mathrm{ml}$ vitamin mixture (Balch et al., 1979)]. Enrichments were started by inoculating $3 \mathrm{ml} \mathrm{Mmj}$ medium with $1 \mathrm{ml}$ sample in $15 \mathrm{ml}$ tubes. The headspace gas was composed of $\mathrm{CH}_{4} / \mathrm{N}_{2} / \mathrm{CO}_{2} /$ $\mathrm{O}_{2}(40: 40: 15: 5 ; 200 \mathrm{kPa})$. The final $\mathrm{pH}$ of Mmj medium with the headspace gas was approximately $\mathrm{pH}$ 6.2. The tubes were incubated for 2 weeks at 55,60 or $70{ }^{\circ} \mathrm{C}$.

Methane-oxidizing coccoid cells grew only in the tube incubated at $55{ }^{\circ} \mathrm{C}$. The enriched culture was purified by a serial dilution-to-extinction technique, which was repeated at least four times before the culture was identified as being pure. The following is a brief description of the technique. An active culture was diluted 1:10 in Mmj medium nine times consecutively. Each tube was incubated under the same conditions as for the enrichment. The most dilute tube indicating cell growth was further diluted and incubated in the same manner. Finally, a $1: 2$ dilution was conducted to obtain a pure culture that theoretically originated from a single cell. The purity of the culture was verified by successful direct sequencing of the partial $16 \mathrm{~S}$ rRNA gene at least three times using independently grown cultures. Growth of the isolate on multicarbon compounds was examined repeatedly but was not observed, indicating that there were no heterotrophic contaminants in the culture. The isolate was designated strain $\mathrm{HTM}_{5} 5^{\mathrm{T}}$. Strain $\mathrm{HTM} 55^{\mathrm{T}}$ was maintained and examined afterwards in $\mathrm{Mmj}$ medium supplemented with a reduced $\mathrm{CuSO}_{4}$ concentration $(1 \mu \mathrm{M})$ because of an obvious inhibitory effect of $\mathrm{CuSO}_{4}$ at concentrations above $4 \mu \mathrm{M}$. All cultivations were in liquid Mmj medium with the same headspace gas composition as the enrichment, unless otherwise mentioned. Colony formation was examined twice on $\mathrm{Mmj}$ agar with incubation in a gas-tight chamber containing $\mathrm{CH}_{4} / \mathrm{N}_{2} / \mathrm{CO}_{2} / \mathrm{O}_{2}(40: 45: 5: 10 ; 100 \mathrm{kPa})$; however, colony formation was not observed after 3 weeks. Therefore, the ability of strain $\mathrm{HTM} 55^{\mathrm{T}}$ to form colonies has not yet been demonstrated.

Cell morphology was determined by phase-contrast microscopy with an Olympus BX51 microscope and by electron microscopy with a JEOL JEM-1210 electron microscope at $120 \mathrm{kV}$. Cells of strain HTM55 $5^{\mathrm{T}}$ in exponential and early stationary phase were coccoid, $0.8-1.4 \mu \mathrm{m}$ in diameter and motile with a single polar flagellum (Fig. 1a, b). Electron microscopy of negatively stained cells revealed a lot of flagella removed from the cells, with only a few of the cells connected to the flagellum. It is unclear whether the flagella fell out actively or whether they were removed passively by physical impact during cultivation or sample preparation. No cystlike cells were evident in the culture after 1 month of storage at growth temperatures. A bundle of type I intracytoplasmic membranes was observed in the ultrathin sections of the cells (Fig. 1c, d). Most of the cells contained intracellular inclusions, seen as low-electron density granules, probably comprising poly- $\beta$-hydroxybutyrate (Fig. 1b, c).

Utilization of various energy and carbon sources other than methane was examined by adding one of the following substrates to $\mathrm{Mmj}$ medium: $0.05 \%$ (w/v) formate, acetate, citrate, succinate, glucose, fructose, ribose, mannitol, methylamine, dimethylamine, methanol, ethanol and 2propanol or $0.1 \%(\mathrm{w} / \mathrm{v})$ yeast extract and Casamino acids. Methane in the headspace of the tube was replaced with $\mathrm{N}_{2}$ in these experiments. Strain HTM55 ${ }^{\mathrm{T}}$ was found to grow only on methane and methanol as the carbon and energy source. Growth on methanol was further tested at different concentrations $(0.025-3 \%, v / v)$. Strain HTM $55^{\mathrm{T}}$ grew at all methanol concentrations tested and the highest cell density was achieved at $0.5 \%$ methanol. None of the other substrates supported growth. Nitrogen sources were examined by adding one of the following substrates $(0.05 \%, \mathrm{w} / \mathrm{v})$ to Mmj medium instead of both $\mathrm{NH}_{4} \mathrm{Cl}$ and $\mathrm{NaNO}_{3}$ : $\mathrm{NH}_{4} \mathrm{Cl}, \mathrm{NaNO}_{3}, \mathrm{NaNO}_{2}$, Tris, urea, formamide, methylamine, dimethylamine, Casamino acids, glycine, L-tryptophan, L-lysine, L-glutamic acid or L-aspartic acid. Strain HTM55 ${ }^{\mathrm{T}}$ grew well with $\mathrm{NH}_{4} \mathrm{Cl}, \mathrm{NaNO}_{3}, \mathrm{NaNO}_{2}$, Casamino acids and L-aspartic acid as the nitrogen source. Weak growth was observed with Tris, urea, L-lysine and L-glutamic acid. No growth was observed with any of the other nitrogen sources tested (formamide, methylamine, dimethylamine, glycine and L-tryptophan). In addition, no growth was found with $\mathrm{N}_{2}$ in the headspace gas in the absence of any other nitrogen compounds. PCR experiments using two pairs of reported primers to amplify the nifH gene, which encodes the nitrogenase iron protein involved in nitrogen fixation, also did not generate plausible amplification products from strain $\mathrm{HTM} 5^{\mathrm{T}}$ DNA (Mehta et al., 2003; Zehr \& McReynolds, 1989). Three strains, Methylococcus 

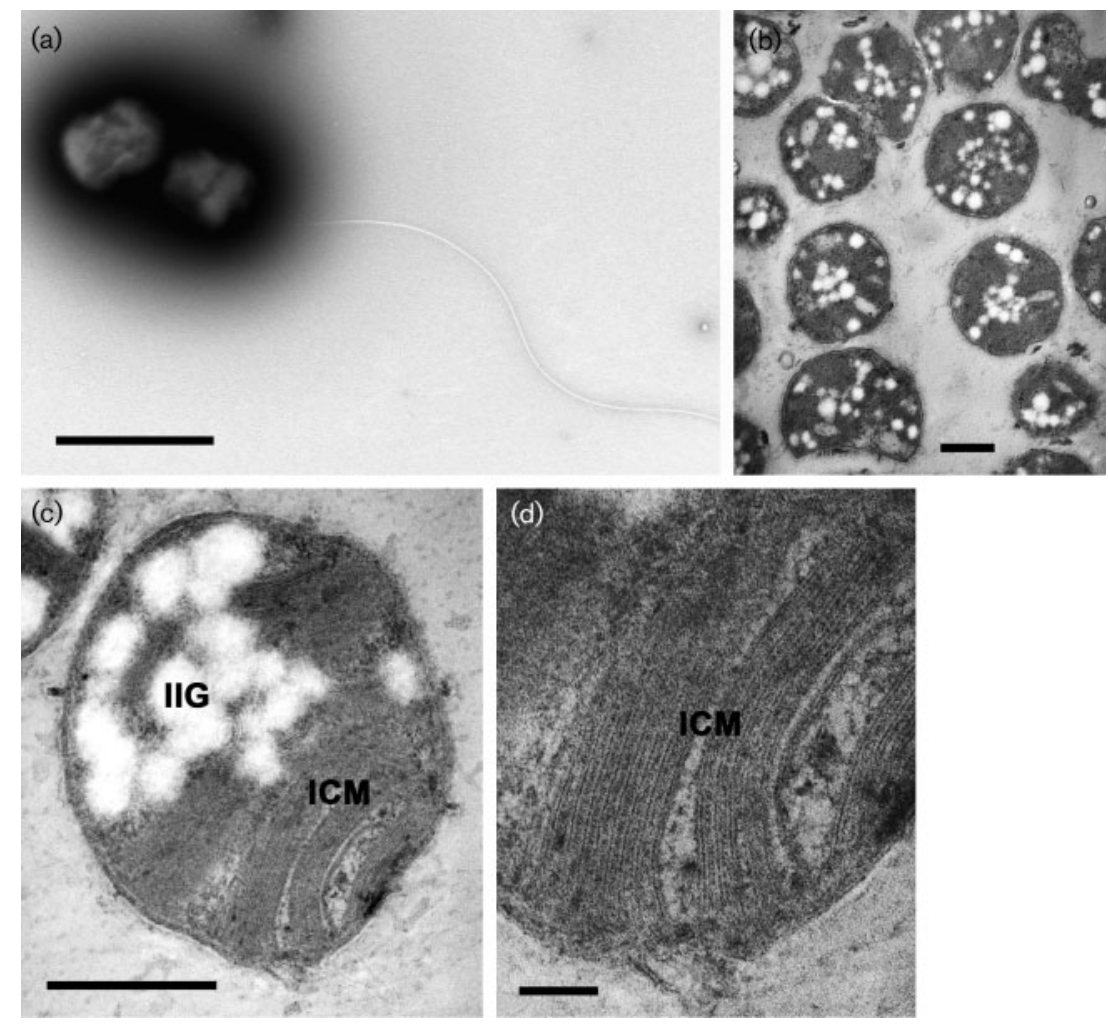

Fig. 1. Transmission electron micrographs of ultrathin sections of strain $\mathrm{HTM}^{\mathrm{T}}{ }^{\mathrm{T}}$. ICM, intracytoplasmic membrane; IIG, intracellular inclusions of granules. Bars, $2 \mu \mathrm{m}$ (a), $0.5 \mu \mathrm{m}$ (b, c) and $0.1 \mu \mathrm{m}(\mathrm{d})$.

capsulatus ATCC $19069^{\mathrm{T}}$, Methylosinus sporium DSM $17706^{\mathrm{T}}$ and Methylocella silvestris DSM $15510^{\mathrm{T}}$, were used as positive controls in the nifH amplification.

Growth conditions for temperature, $\mathrm{pH}, \mathrm{NaCl}$ concentration and $\mathrm{Cu}^{2+}$ concentration on methane were examined in Mmj medium and are summarized in Table 1. Strain HTM $55^{\mathrm{T}}$ grew at $37-65{ }^{\circ} \mathrm{C}$ (optimum $55-60{ }^{\circ} \mathrm{C}$ ); no growth was observed below $33{ }^{\circ} \mathrm{C}$ or above $68{ }^{\circ} \mathrm{C}$. The effects of $\mathrm{pH}$ and $\mathrm{NaCl}$ concentration on growth were tested at $55^{\circ} \mathrm{C}$. The $\mathrm{pH}$ of Mmj medium was adjusted with $\mathrm{HCl}$ or $\mathrm{NaOH}$ after the tube was sealed with headspace gas. Strain $\mathrm{HTM} 55^{\mathrm{T}}$ grew at pH 5.2-7.5 (optimum pH 5.8-6.3); no growth was observed at pH 5.0 or 8.0 . Strain HTM $55^{\mathrm{T}}$ was moderately acidophilic compared to other thermophilic type I methanotrophs (Table 1). Strain HTM55 ${ }^{\mathrm{T}}$ grew with $0-1 \%(\mathrm{w} / \mathrm{v})$ $\mathrm{NaCl}$ (optimum $0-0.3 \% \mathrm{NaCl}$ ); no growth was observed with $1.5 \% \mathrm{NaCl}$. The effect of $\mathrm{Cu}^{2+}$ concentration on growth was tested under optimum growth conditions $\left(55{ }^{\circ} \mathrm{C}\right.$, pH 6.3 and $\left.0.3 \% \mathrm{NaCl}\right)$. Strain $\mathrm{HTM} 55^{\mathrm{T}}$ grew with $0-3 \mu \mathrm{M} \mathrm{CuSO}_{4}$ and optimum growth was observed with $0.5 \mu \mathrm{M} \mathrm{CuSO}_{4}$ (specific growth rate: $0.30 \mathrm{~h}^{-1}$; doubling time: $2.3 \mathrm{~h}$ ). The final cell yield was $2-7 \times 10^{7} \mathrm{ml}^{-1}$ and the $\mathrm{OD}_{660}$ was $0.07-0.25 . \mathrm{CuSO}_{4}$ concentrations above $4 \mu \mathrm{M}$ had an inhibitory effect on growth and the presence of $20 \mu \mathrm{M} \mathrm{CuSO}{ }_{4}$ completely inhibited the growth of strain HTM $55^{\mathrm{T}}$. The growth rate and cell yield on methanol $(0.5 \%, v / v)$ were equal to those on methane.

The presence of soluble methane monooxygenase (sMMO) in strain HTM $55^{\mathrm{T}}$ was tested both by an enzyme activity assay and PCR amplification. To measure sMMO activity, the naphthalene oxidation assay for a liquid culture (Csáki et al., 2003) was performed with whole cells of strain $\mathrm{HTM}_{5}{ }^{\mathrm{T}}$ grown without a $\mathrm{Cu}^{2+}$ supplement. The genes $m m o X, m m o Y, m m o Z, m m o B$ and $m m o C$, which encode sMMO, were examined by PCR amplification as described elsewhere (McDonald et al., 1995; Miguez et al., 1997). The presence of sMMO in strain HTM $55^{\mathrm{T}}$ was not proven by any of these methods. Meanwhile, the presence of particulate methane monooxygenase (pMMO) was confirmed by the identification of PmoA by PCR and sequencing experiments (see below).

To determine carbon fixation capabilities, a cell-free extract was prepared from a cell pellet $(0.3-0.5 \mathrm{~g}$, wet weight) harvested during the exponential growth phase. The cells were resuspended in $3 \mathrm{ml} 0.1 \mathrm{M}$ potassium phosphate buffer ( $\mathrm{pH}$ 7.0) to assay for hexulose phosphate synthase and hydroxypyruvate reductase or $3 \mathrm{ml} 0.1 \mathrm{M}$ HEPES/NaOH ( $\mathrm{pH} 8.3), 10 \mathrm{mM} \mathrm{MgCl}_{2}$ buffer to assay for ribulose 1,5bisphosphate carboxylase/oxygenase (Rubisco). The cell suspension was sonicated for four periods of $30 \mathrm{~s}(150 \mathrm{~W}$, $20 \mathrm{kHz}$ ) with ice-cooling and then centrifuged at $15000 \mathrm{~g}$ for $10 \mathrm{~min}$. The supernatant was used for the enzyme activity assays. For hexulose phosphate synthase in the ribulose monophosphate (RuMP) pathway, the colorimetric assay was carried out as described by Bodrossy et al. (1997), except for a minor change in the formaldehyde concentration in this study. The formaldehyde concentration in the enzyme reaction solution was reduced to one-tenth of the original method because the original concentration $(67 \mathrm{mM})$ failed 
Table 1. Characteristics of strain $\mathrm{HTM}^{\mathrm{T}} 5^{\mathrm{T}}$ and physiologically and phylogenetically related gammaproteobacterial methanotrophs

Strains: 1, HTM55 ${ }^{\mathrm{T}}$ (this study); 2, Methylothermus thermalis MYHT ${ }^{\mathrm{T}}$ (Tsubota et al., 2005); 3, Methylocaldum (Methylocaldum szegediense $\mathrm{OR}^{\mathrm{T}}$, strain O-12 and/or strain H-11; Bodrossy et al., 1997; Eshinimaev et al., 2004); 4, Methylococcus thermophilus (6 strains; Bowman et al., 1993); 5, Methylohalobius crimeensis $10 \mathrm{Ki}^{\mathrm{T}}$ and $4 \mathrm{Kr}$ (Heyer et al., 2005). +, Positive; +/-, strain dependent; -, negative; ND, no data available.

\begin{tabular}{|c|c|c|c|c|c|}
\hline Characteristic & 1 & 2 & 3 & 4 & 5 \\
\hline \multicolumn{6}{|l|}{ Temperature for growth $\left({ }^{\circ} \mathrm{C}\right)$} \\
\hline Range & $37-65$ & $37-67$ & $30-62$ & $37-55$ & $15-42$ \\
\hline \multicolumn{6}{|l|}{$\mathrm{pH}$ for growth } \\
\hline Range & $5.2-7.5$ & $6.5-7.5$ & $6-8.5$ & $5.5-9.0$ & $6.5-7.5$ \\
\hline Optimum & $5.8-6.3$ & 6.8 & $7.1-7.2$ & ND & 7.0 \\
\hline Range & $0-1$ & $0-3$ & $0-0.5$ & $0-3$ & $1.2-15$ \\
\hline Optimum & $0-0.3$ & $0.5-1$ & 0.1 & $\mathrm{ND}$ & $5.8-8.7$ \\
\hline \multicolumn{6}{|l|}{ Activity of key enzyme in: } \\
\hline RuMP pathway & + & + & + & + & + \\
\hline Serine pathway & - & - & + & - & - \\
\hline Calvin-Benson cycle & - & - & + & + & $\mathrm{ND}$ \\
\hline \multicolumn{6}{|l|}{ Major fatty acids (\%) } \\
\hline $\mathrm{C}_{16: 0}$ & 52.0 & 37.2 & $63.7-65.0$ & $39.7-47.0$ & $22.8-23.0$ \\
\hline $\mathrm{C}_{18: 1} \omega 7 c$ & 34.8 & - & - & - & $51.9-60.5$ \\
\hline $\mathrm{C}_{18: 1} \omega 9 c$ & - & 35.2 & - & - & - \\
\hline $\mathrm{C}_{16: 1}$ & - & - & $11.9-13.3$ & - & - \\
\hline $\mathrm{C}_{16: 1} \omega 7 c$ & - & - & - & $17.2-45.9$ & - \\
\hline DNA G $+C$ content $(\mathrm{mol} \%)$ & $54.4 \pm 0.4^{\star}$ & 62.5 & $56.5-58.5$ & 59-61 & $58.6-58.8$ \\
\hline
\end{tabular}

${ }^{\star}$ The value is a mean of three determinations.

to lead to reasonable colour development in the following colorimetric assay developed by Nash (1953). Two negative controls were employed in the colorimetric assay: (1) a reaction without ribulose-5-phosphate; and (2) a reaction with the inactivated enzyme by heating at $96{ }^{\circ} \mathrm{C}$ for $15 \mathrm{~min}$. Hydroxypyruvate reductase in the serine pathway was assayed as described by Large \& Quayle (1963) and Rubisco in the Calvin-Benson cycle was assayed as described by Maeda et al. (2002).

Hexulose phosphate synthase activity was detected, indicating that strain $\mathrm{HTM} 55^{\mathrm{T}}$ assimilated carbon by the RuMP pathway. The presence of the RuMP pathway was further suggested by the presence of the $h p s$ and phi genes encoding 3-hexulose6-phosphate synthase and 6-phospho-3-hexuloisomerase, respectively. The complete sequences of $h p s$ and phi from strain $\mathrm{HTM} 55^{\mathrm{T}}$ were determined on the basis of the results of the metagenomic analyses used for this gold mine environment (H. Takami, S. Nishi \& A. Toyoda, unpublished data).

Neither activity of hydroxypyruvate reductase in the serine pathway nor activity of Rubisco in the Calvin-Benson cycle was detected. PCR amplification of $c b b L$ encoding the large subunit of Rubisco was also attempted using three pairs of primers as reported elsewhere (Alfreider et al., 2003; Elsaied \& Naganuma, 2001; Nanba et al., 2004), but no plausible amplification products were generated.

In each experiment for metabolic enzymes and genes, Methylococcus capsulatus ATCC $19069^{\mathrm{T}}$, Methylosinus sporium DSM $17706^{\mathrm{T}}$, Methylocella silvestris DSM $15510^{\mathrm{T}}$ or Thiobacter subterraneus JCM $12421^{\mathrm{T}}$ were used as positive or negative controls. Representative metabolic characteristics of strain $\mathrm{HTM} 55^{\mathrm{T}}$ and those of physiologically and phylogenetically related gammaproteobacterial methanotrophs are summarized in Table 1.

For analysis of the whole-cell fatty acids of strain HTM $55^{\mathrm{T}}$, fatty acid methyl esters were prepared as described previously (Hirayama et al., 2005a) using cells grown exponentially at $55{ }^{\circ} \mathrm{C}$. Fatty acid methyl esters were extracted with hexane and analysed using a Finnigan TRACE DSQ GC-MS system (Thermo Fisher Scientific) equipped with a polar capillary column SP-2560 (Supelco, $100 \mathrm{~m} \times 0.25 \mathrm{~mm} \times 0.2 \mu \mathrm{m}$ ) under a helium flow of $1.8 \mathrm{ml} \mathrm{min}{ }^{-1}$ and an oven temperature program increasing from $155^{\circ} \mathrm{C}(1 \mathrm{~min})$ to $175^{\circ} \mathrm{C}$ at $1{ }^{\circ} \mathrm{C} \mathrm{min}{ }^{-1}$. The major fatty acids of strain HTM $55^{\mathrm{T}}$ and related methanotrophs are summarized in Table 1 and the 
detailed compositions are given in Supplementary Table S1 (available in IJSEM Online). The major fatty acids of strain HTM $55^{\mathrm{T}}$ were $\mathrm{C}_{16: 0}(52.0 \%)$ and $\mathrm{C}_{18: 1} \omega 7 \mathrm{c}$ (11-cis-octadecenoic acid; $34.8 \%) . \mathrm{C}_{16: 0}$ is a major component in thermophilic and thermotolerant species of proteobacterial type I methanotrophs. Mesophilic strains of the genus Methylohalobius, the closest genus to Methylothermus, also indicate relatively high $\mathrm{C}_{16: 0}$ ratios (Heyer et al., 2005). Other type I methanotrophs belonging to the genera Methylomonas, Methylobacter, Methylomicrobium, Methylosarcina, Methylosphaera and Methylosoma contain less than $20 \% \mathrm{C}_{16: 0}$ fatty acids (Bowman et al., 1993, 1995, 1997; Kalyuzhnaya et al., 2005; Rahalkar et al., 2007). It was revealed that both strain $\mathrm{HTM}^{\mathrm{T}} 5^{\mathrm{T}}$ and Methylothermus thermalis MYHT $^{\mathrm{T}}$ possess $\mathrm{C}_{18: 1}$ fatty acids as major components. Other studies showed that $\mathrm{C}_{18: 1}$ fatty acids are, if contained, only minor components in most type I methanotrophs, including the thermophilic strains of the genera Methylocaldum and Methylococcus (Bowman et al., 1993, 1995, 1997; Eshinimaev et al., 2004; Kalyuzhnaya et al., 2005; Rahalkar et al., 2007). An exception is the mesophilic strains of Methylohalobius, which are reported to contain more than $50 \% \mathrm{C}_{18: 1} \omega 7 c$ (Heyer et al., 2005). The thermotolerant Methylohalobius sp. IT-9 (Hirayama et al., 2007) also contains $49.6 \% \mathrm{C}_{18: 1}$ (H. Hirayama, T. Nunoura \& K. Takai, unpublished data). The predominance of fatty acid $\mathrm{C}_{18: 1}$ may be one of the characteristics commonly found in the phylogenetically related genera Methylothermus and Methylohalobius. Meanwhile, $\mathrm{C}_{18: 1}$ fatty acids are generally abundant in the type II methanotrophs of the class Alphaproteobacteria (Bowman et al., 1993; Dedysh et al., 2007).

The $\mathrm{G}+\mathrm{C}$ content of the genomic DNA was determined as described by Tamaoka \& Komagata (1984). The G+C content of strain $\mathrm{HTM} 55^{\mathrm{T}}$ was $54.4 \mathrm{~mol} \%$, which is similar to the values of thermophilic members of the genus Methylocaldum (56.5-58.5 mol\%) (Bodrossy et al., 1997; Eshinimaev et al., 2004). However, the G $+\mathrm{C}$ content of strain $\mathrm{HTM}_{5} 5^{\mathrm{T}}$ was far lower than that of Methylothermus thermalis $\mathrm{MYHT}^{\mathrm{T}}$ (62.5 mol\%; Table 1).

The nearly complete sequence (1444 bp) of the 16S rRNA gene from strain $\mathrm{HTM}_{5} 5^{\mathrm{T}}$ was amplified by PCR as described previously (Hirayama et al., 2005b) and directly sequenced from both strands with a DNA sequencer (model 3130; Applied Biosystems). The 16S rRNA gene sequence was subjected to similarity analysis using the FASTA algorithm (http://fasta.ddbj.nig.ac.jp/top-j.html) and GENETYX-MAC version 14.0.5 software (Genetyx). The closest relatives of strain $\mathrm{HTM} 55^{\mathrm{T}}$ were the environmental clone HAuD-UB26, which had been obtained previously from the same gold mine environment (99.6\% 16S rRNA gene sequence similarity; Hirayama et al., 2005b) and Methylothermus thermalis $\mathrm{MYHT}^{\mathrm{T}}$ (99.2\%; Tsubota et al., 2005). The results strongly indicated that strain HTM $55^{\mathrm{T}}$ belonged to the genus Methylothermus. Strain HTM $55^{\mathrm{T}}$ was moderately related to Methylothermus sp. HB (92.6\%; Bodrossy et al., 1999) and the mesophilic and halophilic strain Methylohalobius crimeensis $10 \mathrm{Ki}^{\mathrm{T}}$ (90.5\%; Heyer et al., 2005). Members of other methanotrophic genera were only distantly related to strain $\mathrm{HTM}_{5} 5^{\mathrm{T}}(\leqslant 88.1 \%)$.

For phylogenetic analysis, 16S rRNA gene sequences from type I and type X methanotrophic bacteria of the class Gammaproteobacteria were aligned using ARB software and corrected manually where necessary. Only unambiguously aligned nucleotide positions were used for the analysis. A phylogenetic tree was constructed using 835 sequence positions using the neighbour-joining algorithm in the SeaView version 4.0 package and evolutionary distances estimated with Kimura's correction. The phylogenetic tree indicated that strain $\mathrm{HTM} 55^{\mathrm{T}}$ belonged to a deeply branching and distinct lineage comprising the genera Methylothermus and Methylohalobius within the type I and type X methanotrophs of the class Gammaproteobacteria (Fig. 2).

To amplify the full sequence of $p m o A$, the following primers were developed on the basis of full sequences of the pmoCAB operons (encoding pMMO) from the GenBank database: pmoC-F2 5'-GGTCCGTTCATGATYCTGCC-3' and pmoB-R1 5'-TCARGTCRWACCAGTGRAT-3', corresponding to positions 646-665 of pmoC and 139-157 of pmoB, respectively, of Methylococcus capsulatus Bath (GenBank accession no. U94337). Amplification was performed with Ex Taq polymerase (TaKaRa Bio) with the following 30 -cycle programme; $96{ }^{\circ} \mathrm{C}$ for $25 \mathrm{~s}, 45{ }^{\circ} \mathrm{C}$ for $45 \mathrm{~s}$ and $72{ }^{\circ} \mathrm{C}$ for $90 \mathrm{~s}$. The PCR fragment (approx. $1.3 \mathrm{~kb}$ ) was directly sequenced from both strands and subjected to similarity analysis as described above. As summarized in Supplementary Table S2, the $p m o A$ sequence of strain HTM $55^{\mathrm{T}}$ was very similar to the environmental pmoA clone pmoU-1, which was isolated from the same gold mine environment (99.0\% gene sequence similarity, $100 \%$ amino acid sequence similarity; Hirayama et al., 2005b), Methylothermus thermalis $\mathrm{MYHT}^{\mathrm{T}}$ ( $98.7 \%$ gene sequence similarity, $100 \%$ amino acid sequence similarity) and Methylothermus sp. HB (90.6\% gene sequence similarity, $97.7 \%$ amino acid sequence similarity). Strain $\mathrm{HTM} 55^{\mathrm{T}}$ was also related to Methylohalobius crimeensis $10 \mathrm{Ki}^{\mathrm{T}}$ ( $83.0 \%$ gene sequence similarity, $92.1 \%$ amino acid sequence similarity). The alignment of the deduced partial $p m o A$ sequences from various methanotrophs (nine genera of type I and one genus of type II) presented several distinctive residues that were shared with the genera Methylothermus and Methylohalobius (Supplementary Fig. S1).

The similarities between members of the genera Methylothermus and Methylohalobius in the 16S rRNA gene and $p m o A$ sequences are consistent with the reports by Heyer et al. (2005) and Tsubota et al. (2005), suggesting that these two genera within the currently known gammaproteobacterial genera are closely related.

Because the 16S rRNA gene sequence of strain $\mathrm{HTM}^{\mathrm{T}}{ }^{\mathrm{T}}$ was quite similar to that of Methylothermus thermalis $\mathrm{MYHT}^{\mathrm{T}}$, genomic relatedness between these strains was examined by DNA-DNA hybridization $\left(37^{\circ} \mathrm{C}, 4 \mathrm{~h}\right)$ as described by Ezaki et al. (1989) using DNA from both strains as probes in reciprocal experiments. DNA-DNA relatedness between 


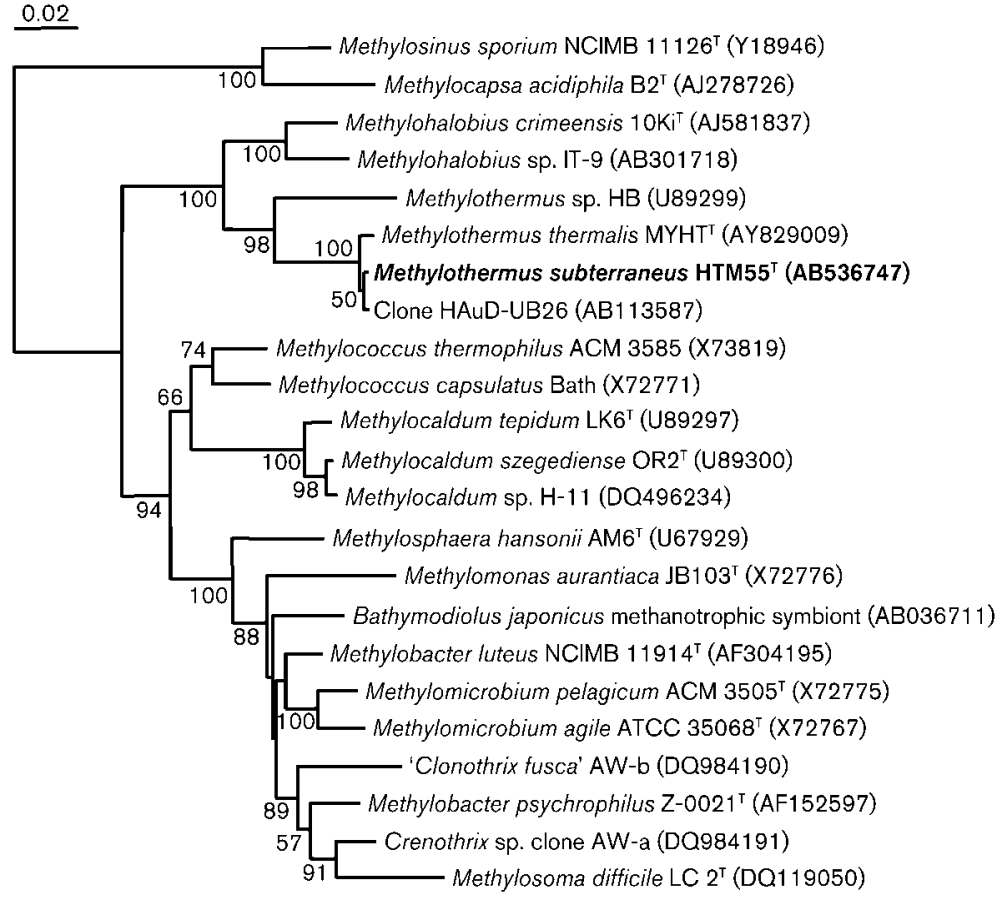

Fig. 2. Neighbour-joining phylogenetic tree based on 16S rRNA gene sequences showing the position of strain $\mathrm{HTM} 55^{\top}$ among representative methanotrophs and the closest environmental clone of the class Gammaproteobacteria. Bootstrap values $(>50 \%)$ based on 100 replicates are shown at branch nodes. Methylosinus sporium NCIMB $11126^{\top}$ and Methylocapsa acidiphila $\mathrm{B}^{\top}$, of the class Alphaproteobacteria, were used as an outgroup. Bar, 2 substitutions per $100 \mathrm{nt}$ positions. these strains was $\leqslant 39 \%$. Generally, strains showing $<70 \%$ DNA-DNA relatedness are recognized as representing separate species (Wayne et al., 1987). According to this criterion, strain $\mathrm{HTM} 55^{\mathrm{T}}$ represents a novel species of the genus Methylothermus.

Other characteristics also distinguished strain HTM55 ${ }^{\mathrm{T}}$ from Methylothermus thermalis $\mathrm{MYHT}^{\mathrm{T}}$, as shown in Table 1. The difference in the DNA $\mathrm{G}+\mathrm{C}$ content between both strains was as much as $8.1 \mathrm{~mol} \%$. Both strains possessed $\mathrm{C}_{18: 1}$ fatty acids; however, the predominant fatty acid in strain $\mathrm{HTM}_{5}{ }^{\mathrm{T}}$ was $\mathrm{C}_{18: 1} \omega 7 c$ (11-cis-octadecenoic acid) while that of Methylothermus thermalis $\mathrm{MYHT}^{\mathrm{T}}$ is reported as $\mathrm{C}_{18: 1} \omega 9 c$ (9-cis-octadecenoic acid). The optimum growth temperatures of the two strains were similar. However, strain HTM $55^{\mathrm{T}}$ preferred more acidic conditions and lower salinity than Methylothermus thermalis $\mathrm{MYHT}^{\mathrm{T}}$; the optimum $\mathrm{pH}$ for strain HTM55 ${ }^{\mathrm{T}}$ (pH 5.8-6.3) was out of the range for Methylothermus thermalis $\mathrm{MYHT}^{\mathrm{T}}$ ( $\mathrm{pH}$ 6.5-7.5). The strains also differed in their abilities to utilize the nitrogen sources nitrite, aspartic acid, tryptophan and formamide; strain HTM55 ${ }^{\mathrm{T}}$ grew with nitrite and aspartic acid, but not with tryptophan and formamide, and vice versa for Methylothermus thermalis $\mathrm{MYHT}^{\mathrm{T}}$. Unlike Methylothermus thermalis $\mathrm{MYHT}^{\mathrm{T}}$, microscopy showed that cells of strain HTM55 ${ }^{\mathrm{T}}$ were motile, possessed a single flagellum and produced many intracellular inclusions (Fig. 1).

Considering these differences in morphological, physiological and chemotaxonomic characteristics between strain HTM55 ${ }^{\mathrm{T}}$ and Methylothermus thermalis $\mathrm{MYHT}^{\mathrm{T}}$, in addition to the phylogenetic analysis, it is evident that strain $\mathrm{HTM} 55^{\mathrm{T}}$ represents a novel species of the genus Methylothermus, for which the name Methylothermus subterraneus sp. nov. is proposed.

\section{Emended description of the genus Methylothermus Tsubota et al. 2005}

Methylothermus (Me.thy'lo.ther'mus. N.L. n. methyl the methyl group; N.L. masc. subst. from Gr. adj. thermos hot; Methylothermus methyl-using thermotolerant organism).

Gram-negative, motile or non-motile coccoids, 0.6-1.4 $\mu \mathrm{m}$ in diameter. Reproduction by normal cell division, with no resting stages (exospores, Azotobacter-type cysts and lipid cysts). Members possess pMMO and a typical type I intracytoplasmic membrane system, but not sMMO. Moderate thermophiles; grow at $37-67{ }^{\circ} \mathrm{C}$ (optimum 55$60{ }^{\circ} \mathrm{C}$ ). Obligate methanotrophs; utilize methane or methanol via the RuMP pathway. The major fatty acids are $C_{16: 0}$ and $\mathrm{C}_{18: 1}$. Belongs to the class Gammaproteobacteria (type I methanotrophs); the closest genus is Methylohalobius. Habitats are terrestrial hot springs. The type species is Methylothermus thermalis.

\section{Description of Methylothermus subterraneus sp. nov.}

Methylothermus subterraneus (sub.ter.ra' ne.us. L. masc. adj. subterraneus under the earth, indicating the first isolation source).

Shows the following characteristics in addition to those given in the genus description. Motile coccoids, 0.8$1.4 \mu \mathrm{m}$ in diameter. Grows at $37-65{ }^{\circ} \mathrm{C}$ (optimum 55$60{ }^{\circ} \mathrm{C}$ ) and $\mathrm{pH}$ 5.2-7.5 (optimum $\mathrm{pH}$ 5.8-6.3). Grows well without $\mathrm{NaCl}$ (optimum $0-0.3 \% \mathrm{NaCl}$ ), but not with $1.5 \% \mathrm{NaCl}$. Utilizes methane and methanol via the RuMP pathway and grows on ammonia, nitrate, nitrite, Casamino acids, L-aspartic acid, L-lysine, L-glutamic acid, Tris and 
urea as nitrogen sources. The major fatty acids are $\mathrm{C}_{16: 0}$ and $\mathrm{C}_{18: 1} \omega 7 c$.

The type strain, $\mathrm{HTM}^{\mathrm{T}} 5^{\mathrm{T}}\left(=\mathrm{JCM} 13664^{\mathrm{T}}=\mathrm{DSM} 19750^{\mathrm{T}}\right.$ ), was isolated from subsurface hot aquifer water in the Hishikari gold mine, Kagoshima, Japan. The DNA G + C content of the type strain is $54.4 \mathrm{~mol} \%$.

\section{Acknowledgements}

We are grateful to Sumitomo Metal Mining Co. Ltd. for cooperation in this study and to $\mathrm{Mr} \mathrm{A}$. Tame for assistance with the electron micrography. We would like to thank Dr J. Tsubota for supplying us with a culture of Methylothermus thermalis $\mathrm{MYHT}^{\mathrm{T}}$.

\section{References}

Alfreider, A., Vogt, C., Hoffmann, D. \& Babel, W. (2003). Diversity of ribulose-1,5-bisphosphate carboxylase/oxygenase large-subunit genes from groundwater and aquifer microorganisms. Microb Ecol 45, 317328.

Balch, W. E., Fox, G. E., Magrum, L. J., Woese, C. R. \& Wolfe, R. S. (1979). Methanogens: reevaluation of a unique biological group. Microbiol Rev 43, 260-296.

Bodrossy, L., Holmes, E. M., Holmes, A. J., Kovács, K. L. \& Murrell, J. C. (1997). Analysis of $16 \mathrm{~S}$ rRNA and methane monooxygenase gene sequences reveals a novel group of thermotolerant and thermophilic methanotrophs, Methylocaldum gen. nov. Arch Microbiol 168, 493503.

Bodrossy, L., Kovács, K. L., McDonald, I. R. \& Murrell, J. C. (1999). A novel thermophilic methane-oxidising $\gamma$-Proteobacterium. FEMS Microbiol Lett 170, 335-341.

Bowman, J. P., Sly, L. I., Nichols, P. D. \& Hayward, A. C. (1993). Revised taxonomy of the methanotrophs: description of Methylobacter gen. nov., emendation of Methylococcus, validation of Methylosinus and Methylocystis species, and a proposal that the family Methylococcaceae includes only the group I methanotrophs. Int J Syst Bacteriol 43, 735-753.

Bowman, J. P., Sly, L. I. \& Stackebrandt, E. (1995). The phylogenetic position of the family Methylococcaceae. Int J Syst Bacteriol 45, 182185.

Bowman, J. P., McCammon, S. A. \& Skerratt, J. H. (1997). Methylosphaera hansonii gen. nov., sp. nov., a psychrophilic, group I methanotroph from Antarctic marine-salinity, meromictic lakes. Microbiology 143, 1451-1459.

Csáki, R., Bodrossy, L., Klem, J., Murrell, J. C. \& Kovács, K. L. (2003). Genes involved in the copper-dependent regulation of soluble methane monooxygenase of Methylococcus capsulatus (Bath): cloning, sequencing and mutational analysis. Microbiology 149, 1785-1795.

Dedysh, S. N., Belova, S. E., Bodelier, P. L. E., Smirnova, K. V., Khmelenina, V. N., Chidthaisong, A., Trotsenko, Y. A., Liesack, W. \& Dunfield, P. F. (2007). Methylocystis heyeri sp. nov., a novel type II methanotrophic bacterium possessing 'signature' fatty acids of type I methanotrophs. Int J Syst Evol Microbiol 57, 472-479.

Elsaied, H. \& Naganuma, T. (2001). Phylogenetic diversity of ribulose-1,5-bisphosphate carboxylase/oxygenase large-subunit genes from deep-sea microorganisms. Appl Environ Microbiol 67, 1751-1765.

Eshinimaev, B. Ts., Medvedkova, K. A., Khmelenina, V. N., Suzina, N. E., Osipov, G. A., Lysenko, A. M. \& Trotsenko, luA. (2004). New thermophilic methanotrophs of the genus Methylocaldum. Mikrobiologiia 73, 530-539 (in Russian).
Ezaki, T., Hashimoto, Y. \& Yabuuchi, E. (1989). Fluorometric deoxyribonucleic acid-deoxyribonucleic acid hybridization in microdilution wells as an alternative to membrane filter hybridization in which radioisotopes are used to determine genetic relatedness among bacterial strains. Int J Syst Bacteriol 39, 224-229.

Heyer, J., Berger, U., Hardt, M. \& Dunfield, P. F. (2005). Methylohalobius crimeensis gen. nov., sp. nov., a moderately halophilic, methanotrophic bacterium isolated from hypersaline lakes of Crimea. Int J Syst Evol Microbiol 55, 1817-1826.

Hirayama, H., Takai, K., Inagaki, F., Nealson, K. H. \& Horikoshi, K. (2005a). Thiobacter subterraneus gen. nov., sp. nov., an obligately chemolithoautotrophic, thermophilic, sulfur-oxidizing bacterium from a subsurface hot aquifer. Int J Syst Evol Microbiol 55, 467-472.

Hirayama, H., Takai, K., Inagaki, F., Yamato, Y., Suzuki, M., Nealson, K. H. \& Horikoshi, K. (2005b). Bacterial community shift along a subsurface geothermal water stream in a Japanese gold mine. Extremophiles 9, 169-184.

Hirayama, H., Sunamura, M., Takai, K., Nunoura, T., Noguchi, T., Oida, H., Furushima, Y., Yamamoto, H., Oomori, T. \& Horikoshi, K. (2007). Culture-dependent and -independent characterization of microbial communities associated with a shallow submarine hydrothermal system occurring within a coral reef off Taketomi Island, Japan. Appl Environ Microbiol 73, 7642-7656.

Inagaki, F., Takai, K., Hirayama, H., Yamato, Y., Nealson, K. H. \& Horikoshi, K. (2003). Distribution and phylogenetic diversity of the subsurface microbial community in a Japanese epithermal gold mine. Extremophiles 7, 307-317.

Kalyuzhnaya, M. G., Stolyar, S. M., Auman, A. J., Lara, J. C., Lidstrom, M. E. \& Chistoserdova, L. (2005). Methylosarcina lacus sp. nov., a methanotroph from Lake Washington, Seattle, USA, and emended description of the genus Methylosarcina. Int J Syst Evol Microbiol 55, 2345-2350.

Large, P. J. \& Quayle, J. R. (1963). Microbial growth on $C_{1}$ compounds. 5. Enzyme activities in extracts of Pseudomonas AM1. Biochem J 87, 386-396.

Maeda, N., Kanai, T., Atomi, H. \& Imanaka, T. (2002). The unique pentagonal structure of an archaeal Rubisco is essential for its high thermostability. J Biol Chem 277, 31656-31662.

McDonald, I. R., Kenna, E. M. \& Murrell, J. C. (1995). Detection of methanotrophic bacteria in environmental samples with the PCR. Appl Environ Microbiol 61, 116-121.

Mehta, M. P., Butterfield, D. A. \& Baross, J. A. (2003). Phylogenetic diversity of nitrogenase (nifH) genes in deep-sea and hydrothermal vent environments of the Juan de Fuca Ridge. Appl Environ Microbiol 69, 960-970.

Miguez, C. B., Bourque, D., Sealy, J. A., Greer, C. W. \& Groleau, D. (1997). Detection and isolation of methanotrophic bacteria possessing soluble methane monooxygenase (sMMO) genes using the polymerase chain reaction (PCR). Microb Ecol 33, 21-31.

Nanba, K., King, G. M. \& Dunfield, K. (2004). Analysis of facultative lithotroph distribution and diversity on volcanic deposits by use of the large subunit of ribulose 1,5-bisphosphate carboxylase/oxygenase. Appl Environ Microbiol 70, 2245-2253.

Nash, T. (1953). The colorimetric estimation of formaldehyde by means of the Hantzsch reaction. Biochem J 55, 416-421.

Op den Camp, H. J. M., Islam, T., Stott, M. B., Harhangi, H. R., Hynes, A., Schouten, S., Jetten, M. S. M., Birkeland, N.-K., Pol, A. \& Dunfield, P. F. (2009). Environmental, genomic and taxonomic perspectives on methanotrophic Verrucomicrobia. Environ Microbiol Rep 1, 293-306.

Rahalkar, M., Bussmann, I. \& Schink, B. (2007). Methylosoma difficile gen. nov., sp. nov., a novel methanotroph enriched by gradient 
cultivation from littoral sediment of Lake Constance. Int J Syst Evol Microbiol 57, 1073-1080.

Takai, K., Hirayama, H., Sakihama, Y., Inagaki, F., Yamato, Y. \& Horikoshi, K. (2002). Isolation and metabolic characteristics of previously uncultured members of the order Aquificales in a subsurface gold mine. Appl Environ Microbiol 68, 3046-3054.

Takai, K., Kobayashi, H., Nealson, K. H. \& Horikoshi, K. (2003). Sulfurihydrogenibium subterraneum gen. nov., sp. nov., from a subsurface hot aquifer. Int J Syst Evol Microbiol 53, 823-827.

Tamaoka, J. \& Komagata, K. (1984). Determination of DNA base composition by reversed-phase high-performance liquid chromatography. FEMS Microbiol Lett 25, 125-128.
Tsubota, J., Eshinimaev, B. Ts., Khmelenina, V. N. \& Trotsenko, Y. A. (2005). Methylothermus thermalis gen. nov., sp. nov., a novel moderately thermophilic obligate methanotroph from a hot spring in Japan. Int J Syst Evol Microbiol 55, 1877-1884.

Wayne, L. G., Brenner, D. J., Colwell, R. R., Grimont, P. A. D., Kandler, O., Krichevsky, M. I., Moore, L. H., Moore, W. E. C., Murray, R. G. E. \& other authors (1987). Report of the ad hoc committee on reconciliation of approaches to bacterial systematics. Int J Syst Bacteriol 37, 463-464.

Zehr, J. P. \& McReynolds, L. A. (1989). Use of degenerate oligonucleotides for amplification of the nifH gene from the marine cyanobacterium Trichodesmium thiebautii. Appl Environ Microbiol 55, 2522-2526. 